\title{
PERAN PERILAKU KEPEMIMPINAN WAKIL KEPALA SEKOLAH BIDANG KESISWAAN DALAM PENGORGANISASIAN SISWA BERBASIS MEDIA SOSIAL DI SMK KOTA BEKASI
}

\author{
Fetrimen \\ Universitas Muhammadiyah Prof. Dr. HAMKA
}

\begin{abstract}
Principal leadership activities in utilizing social media can affect the effectiveness of organizing, coaching, and communication. This study discusses effective communication with students through utilizing social media. Communication through social media is done by forming groups in various social media. This research was conducted with a survey method that uses data analysis with path analysis methods where calculations are performed with the program used are Data Analysis packages found in Microsoft Excel and SPSS. The subjects of this study were the deputy principals of the Vocational High School students' field of 100 people in the city of Bekasi. The determination of the sample was taken using Slovin formula and random sampling technique, as many as 80 deputy principals in the student field were the sample of the study while 20 deputy principals in the student field were used to test the validation of the research instruments. This research is expected to contribute to society.

Keywords: Leadership activities, organizing, social media
\end{abstract}

Perilaku kepemimpinan kepala sekolah dalam memanfaatkan media sosial dapat mempengaruhi efektifitas pengorganisasian, pembinaan, dan komunikasi. Penelitian ini membahas tentang komunikasi yang efektif dengan para siswa melalui memanfaatkan media sosial. Komunikasi melalui media sosial dilakukan dengan membentuk kelompok-kelompok dalam berbagai media sosial. Penelitian ini dilakukan dengan metode survei yang menggunakan analisis data dengan metode analisis jalur dimana perhitungan dilakukan dengan program yang digunakan adalah paket Data Analysis yang terdapat pada Microsoft Excel dan SPSS. Subyek penelitian ini adalah wakil kepala sekolah bidang kesiswaan sekolah Menengah Kejuruan yang berjumlah 100 orang di kota Bekasi. Adapun penentuan sampel diambil dengan menggunakan rumus slovin dan teknik random sampling, sebanyak 80 orang wakil kepala sekolah bidang kesiswaan menjadi sampel penelitian sedangkan 20 orang wakil kepala sekolah bidang kesiswaan digunakan untuk menguji validasi instrumen penelitian. Penelitian ini, diharapkan memberikan sumbangsih pada masyarakat.

Kata kunci : perilaku kepemimpinan, pengorganisasian dan media sosial 


\section{Pendahuluan}

Dalam pelaksanaan pengorganisasian pembinaan siswa, semua aktivitas sekolah pada umumnya diarahkan untuk membantu siswa mengembangkan potensi diri, baik pada aspek akademis maupun pada aspek lainnya. Pengembangan potensi diri siswa tidak hanya pada ranah kognitif tetapi juga pada ranah psikomotorik dan ranah afektif, sehingga siswa dapat melakukan pengembangan diri secara aktif sesuai dengan minat dan kemampuan yang dapat disesuaikan oleh program-program sekolah. Hal ini sekolah dituntut untuk mengembangkan kegiatan yang beragam, sehingga siswa memiliki wahana untuk berkembang dan siswa akan termotivasi untuk selalu aktif dalam setiap kegiatan.

Penyebab tidak terlaksananya secara optimal pengorganisasian pembinaan siswa adalah para siswa dihadapkan pada beban pendidikan terlalu banyak dan ekspektasi yang terlalu tinggi karena lingkungan yang sangat kompetitif. Sistem pendidikan dan lingkungan tidak memberikan ruang yang cukup pada para siswa untuk mengembangkan konsep diri secara matang dan positif untuk membentuk dan mengembangkan konsep diri yang berkualitas. Pengorganisasian pembinaan siswa yang efektif dapat melibatkan para siswa dalam penyusunan program pembinaan siswa, sehingga siswa termotivasi karena ide dan gagasan para siswa diterima dan dikembangkan. Paradigma perilaku kepemimpinan ini bertujuan untuk melakukan perubahan dengan mencurahkan perhatian guna mewujudkan visi, misi dan tujuan sekolah dengan nilai-nilai keadilan, kebersamaan dan kebebasan terhadap pelaksanaan dan pencapaian tugas dan fungsi kepemimpinan sehingga dapat memotivasi para pembina unit kegiatan sekolah dalam melaksanakan tugasnya. Kemajuan teknologi dapat meningkatkan kepercayaan diri siswa dalam mengembangkan diri dengan cara memanfaatan media sosial dalam pengorganisasian pembinaan siswa yang dilakukan wakil kepala sekolah bidang kesiswaan. Berdasarkan pada uraian latar belakang tersebut, maka menarik untuk dilakukan penelitian tentang efektifitas pengorganisasian pembinaan siswa yang dihubungkan denganperilaku kepemimpinan wakil kepala 
sekolah bidang kesiswaan berbasis media sosial, mengingat efektifnya pengorganisasian pembinaan siswa merupakan faktor yang penting untuk menentukan kualitas pendidikan di sekolah.

Adapun masalah utama dalam penelitian ini adalah mencari jawaban atas pertanyaan berikut : (a) bagaimana perilaku kepemimpinan wakil kepala sekolah bidang kesiswaan dalam memanfaatkan media sosial di Sekolah Menengah Kejuruan Bekasi ?, (b) bagaimana efektifitas perilaku kepemimpinan wakil kepala sekolah bidang kesiswaan dalam menggunakan media sosialmelakukan pengorganisasian pembinaan siswa di Sekolah Menengah Kejuruan Bekasi?, bagaimana komunikasiperilaku kepemimpinan wakil kepala sekolah bidang kesiswaan dengan mengugunakan media sosial dalam melakukan pengorganisasian pembinaan siswa di Sekolah Menengah Kejuruan Bekasi?

\section{Pengorganisasian Siswa}

Pengorganisasian diproses oleh organisator atau manajer sehingga menghasilkan organisasi yang bersifat statis. Jika pengorganisasian baik maka organisasipun akan baik dan tujuan organisasi relatif mudah untuk dicapai. Pengorganisasian adalah suatu proses penentuan, pengelompokan dan pengaturan bermacam-macam aktifitas yang diperlukan untuk mencapai tujuan. Dalam mencapai tujuan maka dibutuhkan penempatan orang-orang pada setiap aktifitas organisasi, menyediakan alatalat yang diperlukan, menetapkan wewenang secara relatif didelegasikan pada setiap individu yang akan melakukan aktifitas-aktifitas tersebut.Manullang mengartikan organisasi dalam bentuk dinamis menjadi pengorganisasian yang merupakan suatu proses penetapan pembagian kerja yang akan dilakukan. Pembatasan-pembatasan pembagian tugas atau tanggungjawab serta wewenang dan penetapan hubunganhubungan antar unsur-unsur dalam organisasi sehingga memungkinkan individu-individu bekerja bersama seefektif mungkin untuk mencapai tujuan. Soekarno, mendefenisikan pengorganisasian sebagai salah satu fungsi manajemen menjadi suatu proses yang memberikan kemungkinan bagi manajemen untuk bergerak dalam batas-batas tertentu dengan mengadakan 
pembagian kerja. ${ }^{1}$ Pengorganisasian merupakan penerapan proses sistem organisasi yang bersifat aktif karena terjadinya berbagai hubungan antara individu dengan individu, individu dengan kelompok yang menghasilkan berbagai kepentingan dalam pencapaian tujuan organisasi yang telah ditentukan. Dalam pandanganHanna, pengorganisasian merupakan suatu sistem yang memahami tentang interaksi antar sub sistem dengan sub sistem lainnya dalam organisasi. ${ }^{2}$ Pengorganisasian sebagai proses pengolompokan orang-orang, tugas-tugas, tanggung jawab dan wewenang untuk membangun komitmen antar unit yang disesuaikan dengan kebutuhan, menciptakan budaya, pemberdayaan dan komunikasi antar unit dengan merumuskan misi dan sistem nilai organisasi. ${ }^{3}$ Efektifitas pengorganisasian pembinaan siswa bertujuan untuk menyeimbangkan kemampuan otak kanan dan otak kiri dalam bentuk kegiatan ekstrkurikuler. Kegiatan siswa, seperti pada sekolah menengah kejuruan, sekolah harus memfasilitasi beberapa kegiatan yang mengarah pada kreatifitas dan inovasi dalam pengembangan bakat dan minat siswa serta pengembangan kepribadian. Sebagai usaha untuk merealisasikan hal tersebut maka wakil kepala sekolah bidang kesiswaan melakukan identifikasi terhadap siswa untuk memotivasinya mengembangkan minat dan bakat serta kepribadian dalam suatu kelompok. Pengembangan kegiatan ekstrakurilkuler dijadikan sebagai wahana untuk mengembangkan sikap yang sportifitas, menghargai karya seni serta kemampuan kecakapan hidup lainnya.

Pada sekolah menengah kejuruan, kegiatan ekstrakurikuler dapat didorong dengan pembentukan klub-klub dalam bidang olah raga, kesenian, pencinta alam maupun klub lainya sesuai dengan minat dan bakat siswa sebagai

${ }^{1}$ Soekarno, Fungsi-Fungsi Manajemen, retrived, 02 Juni 2017 Open pdf.com/ ebook Pengorganisasian- pdf-html.

${ }^{2}$ Hanna, David, Manajemen Pendidikan, Eirlangga, Jakarta, 2015. hlm. 102.

3 Hanaka, Martin E dan Bill Hawkins, Mengorganisasi Untuk Keunggulan Terus-Menerus, Elex Media Komputindo, Jakarta, 2016. Hlm. 201. 
pengembangan potensi sekolah dan keinginan masyarakat disekitar lingkungan sekolah. Dengan adanya klub-klub ini, maka siswa diharapkan dapat meningkatkan prestasinya sesuai dengan minat dan bakatnya untuk membekali siswa setelah keluar dari sekolah mampu bersaing dengan sekolah lain.

Dalam pengorganisasian, tidak ada satu cara pengorganisasian yang berlaku untuk semua tipe organisasi dan berlaku sepanjang masa. Struktur organisasi yang terbaik bergantung pada beberapa hal, antara lain : teknologi yang dipergunakan, lingkungan tempat beroperasi dan sistem nilai yang dianut oleh anggota organisasi. Adapun perbedaan struktur organisasi tergantung kebutuhan antara satu dengan yang lainnya sehingga dapat berubah seiring berjalannya waktu.

\section{Perilaku Kepemimpinan}

Perilaku kepemimpinan merupakan proses terencana yang dinamis melalui suatu periode waktu dalam situasi tertentu yang di dalamnya pemimpin menggunakan perilaku (pola atau gaya) kepemimpinan yang khusus dan sarana serta prasarana kepemimpinan untuk memimpin yakni menggerakan atau mempengaruhi bawahan atau anggotanya guna melaksanakan tugas atau pekerjaan kearah yang dalam upaya mencapai tujuan yang menguntungkan bagi pimpinan dan bawahan serta lingkungan sosial dimana organisasi tersebut berada. ${ }^{4}$ Perilaku kepemimpinan sebagai hubungan yang ada dalam diri seseorang atau pemimpin, mempengaruhi orang lain untuk bekerja secara sadar dalam hubungan tugas untuk mencapai tujuan yang dinginkan sebagai perpaduan perbuatan yang memungkinkan seseorang untuk mampu mendorong pihak lain untuk menyelesaikan tugasnya. ${ }^{5}$

Perilaku kepemimpinan aktivitas untuk mempengaruhi perilaku anggota organisasi agar anggota mau diarahkan untuk mencapai tujuan tertentu. Sedangkan menurut Robbins,

${ }^{4}$ Clinton, J. Robert and Y. Tomatala, The Making of A Leader, Retrieved 3 juli 2017 http : Leadership .blogspot.com/ definition Leadership.html.

${ }^{5}$ Terry and Tead, 2010. Kemimpinan-fisipuh, retrieved 5 juli 2017, blospot.com/.../defenisi kepemimpinan.html. 
perilaku kepemimpinan merupakan kemampuan untuk mempengaruhi suatu kelompok untuk mencapai tujuan tertentu. $^{6}$

Perilaku kepemimpinan merupakan sekumpulan dari serangkain kemampuan dan sifat-sifat kepribadian, termasuk didalamnya kewibawaan, untuk dijadikan sarana dalam rangka meyakinkan anggota yang dipimpinnya agar para anggota mau dan dapat melaksanakan tugas-tugas yang dibebankan pada anggota dengan rela, penuh semangat, ada kegembiraan batin serta merasa terpaksa. ${ }^{7}$ Perilaku kepemimpinan sebagai kemampuan meyakinkan orang lain supaya bekerjasama dibawah pimpinannya sebagai suatu tim untuk mencapai tujuan. $^{8}$ Dalam pandangan Gordon, perilaku kepemimpinan dapat dikonsepsualisasikan sebagai sutu interaksi antara seseorang dengan suatu kelompok atau antara seseorang dengan anggota kelompoknya, dimana setiap anggota dalam interaksi memainkan peranan dan dengan cara tertentu peranan tersebut harus dipilah-pilah antara yang satu dengan yang lainnya dengan dasar pemilahan merupakan persolan pengaruh, dimana pemimpin mempengaruhi dan anggota kelompok dipengaruhi.

Pada institusi pendidikan, perilaku kepemimpinan termasuk dalam kategori kepemimpinan di sekolah selain kepemimpinan pengajaran, moral, pengurusan, penyertaan dan kontigensi. Perilaku kepemimpinan dalam pendidikan merupakan proses mempengaruhi anggota untuk melaksanakan tugasnya melebihi sasaran yang ditetapkan. ${ }^{9}$ Perilaku kepemimpinan merangsang anggota untuk membentuk dan melahirkan wawasan, keterampilan pribadi, keyakinan yang tinggi pada guru, tenaga administrasi termasuk pada para siswa, membangun komunikasi, merangsang intelektualitas dalam

${ }^{6}$ Thoha, Miftah, Kepemimpinan Dalam Manajemen, Rajawali Pers, Jakarta, 2013. hlm. 123.

${ }^{7}$ Purwanto, M. Ngalim, Administrasi dan Supervisi Pendidikan, Remaja Rosda Karya, Bandung, 2011. hlm. 26.

${ }^{8}$ Black, Jack M, Management: A Guide to Executive Command, Ohio: publishing co, Ohio, 2010. hlm. 12.

9 Yahya, Sani, Transformational Leadership, Retrieved 19 Juni 2017, http://Stralead-Change.com/files/corses.htm 
organisasi, perhatian terhadap individu anggota dan menjadi pendengar yang baik.

Indetifikasi terhadap perilaku kepemimpinan agar lebih efektif kedalam lima sistem, antara lain : pertama keinginan untuk menerima tanggung jawab. Seorang pemimpin menerima kewajiban untuk mencapai suatu tujuan, berarti bersedia untuk bertangung jawab pada pimpinannya atas apa yang telah dikerjakan oleh anggotanya dan seharusnya mampu untuk mengatasi tekanan dari para anggota dan tekanan kelompok informal. Kedua kemampuan untuk bisa mengamati dan menemukan kenyataan dari suatu lingkungsn, setiap pemimpin haruslah bekerja berdasarkan pada tujuan organisasi, seorang pemimpin dituntut memahami bawahannya sehingga pemimpin dapat mengetahui kekuatan dan kelemahan serta ambisi yang ada, selain itu, pemimpin harus juga mempunyai persepsi instropektif (menilai diri sendiri) sehingga mengetahui kekuatan, kelemahan dan tujuan yang layak atau kemampuan 'perceptive'. Ketiga kemampuan untuk bersikap objektif. Objektivitas adalah kemampuan untuk menilai suatu peristiwa, objektivitas membantu seorang pemimpin untuk menimukan faktor emosional dan pribadi yang mungkin mengaburkan realitas. Keempat kemampuan untuk menentukan prioritas, seorang pemimpin mempunyai kemampuan untuk memiliki dan menentukan mana yang penting atau tidak. Kemampuan ini sangat dibutuhkan karena pada kenyataan seirng permasalahan datang bukan satu persatu tetapi bersamaan dan berkaitan antara satu dengan yang lainnya. Kelima kemampuan untuk berkomunikasi. Kemampuan untuk memberikan dan menerima informasi merupakan keharusan bagi seorang pemimpin. Pemimpin adalah orang yang bekerja dengan bantuan orang lain, karena itu pemberian perintah dan penyampaian informasi pada orang lain mutlak harus dikuasai.

\section{Media Sosial}


Media sosial Kaplan merupakan saluran atau sarana pergaulan sosial secara online di dunia maya (internet). ${ }^{10}$ Para pengguna (user) media sosial berkomunikasi, berinteraksi, saling kirim pesan, dan saling berbagi (sharing), dan membangun jaringan (networking). Secara umum, makna media sosial diterjemahkan sebagai website dan aplikasi yang digunakan untuk jejaring sosial. Media sosial merupakan suatu media online, dengan para penggunanya (users) bisa dengan mudah berpartisipasi, berbagi, dan menciptakan isi meliputi blog, jejaring sosial, wiki, forum, dan dunia virtual. ${ }^{11}$ Blog, jejaring sosial dan wiki merupakan bentuk media sosial yang paling umum digunakan oleh masyarakat di seluruh dunia. Media sosial suatu kelompok aplikasi berbasis internet yang membangun di atas dasar ideologi dan teknologi Web 2.0, dan yang memungkinkan penciptaan dan pertukaran user-generated content. $^{12}$ Media sosial merupakan alat promosi yang efektif karena dapat diakses oleh siapa saja, sehingga jaringan promosi bisa lebih luas. Media sosial menjadi bagian yang sangat diperlukan oleh pemasaran bagi banyak perusahaan dan merupakan salah satu cara terbaik untuk menjangkau pelanggan dan klien. Media sosial sperti blog, facebook, twitter dan youtube memiliki sejumlah manfaat bagi perusahaan dan lebih cepat dari media konvensional seperti media cetak dan iklan televisi, brosur dan selebaran.

Media sosial memiliki kelebihan dibandingkan dengan media konvensional dengan cara : pertama, kesederhanaan, dalam suatu produksi media konvensional dibutuhkan keterampilan tingkat tinggi dan keterampilan marketing yang unggul. Sedangkan media sosial sangat mudah digunakan,

10 Kaplan, Andreas and Michael Haenlein, Users of the world, unite! The challenges and opportunities of Social Media, Business Horizons, 2010, hlm. 59.

${ }^{11}$ https://id.wikipedia.org/w/index.php?search=media+sosial+adalah \&title=Istimewa:Pencarian\&go=Lanjut\&searchToken=etbiozowy95mfe9of3 qqd1ojc

12 Haenlein, Frances and Marshal Goldsmith, The Leader of The Future: Visi, Strategic dan Praktik Pemimpin Masa Depan Untuk Era Baru, Elex Media Kompetindo, Jakarta, 2017, hlm. 45. 
bahkan untuk orang tanpa dasar teknologi informasi dapat mengaksesnya, yang dibutuhkan hanyalah komputer dan koneksi internet. Kedua, membangun Hubungan, media sosial menawarkan kesempatan tak tertandingi untuk berinteraksi dengan pelanggan dan membangun hubungan. Perusahaan mendapatkan sebuah feedback langsung, ide, pengujian dan mengelola layanan pelanggan dengan cepat. Tidak dengan media tradisional yang tidak dapat melakukan hal tersebut, media tradisional hanya melakukan komunikasi satu arah. Ketiga, jangkauan global, media tradisional dapat menjangkau secara global tetapi tentu saja dengan biaya sangat mahal dan memakan waktu. Adapun fungsi media sosial sebagai sistem komunikasi, maka penggunaan media sosial efektif dilakukan: pertama, administrasi, pengorganisasian profil lembaga dalam jaringan sosial yang relevan dan relatif. Pembentukan pelatihan kebijakan media sosial, dan pendidikan untuk penggunaan media sosial. Pembentukan sebuah blog organisasi dan integrasi konten dalam masyarakat yang relevan. Kedua, mendengarkan dan belajar, pembuatan sistem pemantauan untuk mendengar apa yang diinginkan, apa yang relevan dengan kebutuhan. Ketiga, berpikir dan Perencanaan, teknologi sosial meningkatkan efisiensi program. Keempat, pengukuran, menetapkan langkah-langkah efektif sangat penting untuk mengukur apakah metode yang digunakan, isi dibuat dan alat yang anda gunakan efektif dalam meningkatkan posisi program kegiatan.

Karakteristik media sosial mempunyai ciri - ciri, pertama, pesan yang di sampaikan tidak hanya untuk satu orang saja namun bisa keberbagai banyak orang contohnya pesan melalui SMS ataupun internet, kedua pesan yang di sampaikan bebas, tanpa harus melalui suatu Gatekeeper. ${ }^{13}$ Ketiga, pesan yang di sampaikan cenderung lebih cepat di banding media lainnya. Keempat, penerima pesan yang menentukan waktu interaksi. Sebagai salah satu media komunikasi, media sosial

${ }^{13}$ Reuben, Rachel, The Use of Social Media in Higher Education for Marketing and Communications: A Guide for Professionals in Higher Education, retrieved 5 Juli 2017 From http://www.rachelreuben.com/.../ social-media-uses-higher-education. 
tidak hanya dimanfaatkan untuk berbagi informasi dan inspirasi, tapi juga ekspresi diri, pencitraan diri, dan ajang "curhat" bahkan keluh-kesah dan sumpah-serapah. Status terbaik di media sosial adalah update status yang informatif dan inspiratif.

\section{Efektifitas Pengorganisasian Pembinaan Siswa Berbasis Media Sosial}

Skor efektifitas pengorganisasian pembinaan siswa berbasis media sosial merupakan salah satu perangkat data yang sangat dibutuhkan dalam penelitian ini. Skor efektifitas pengorganisasian pembinaan siswa bebasis media sosial diperoleh dari 36 responden penelitian. Setelah dianalisis maka diperoleh skor maksimum 139 dan skor minimum 89. rentangan datanya $139-89=50$. berdasarkan pada penelitian untuk skor efektifitas pengorganisasian pembinaan siswa berbasis media sosial yang dikumpulkan dengan memakai skala likert, nilai terendah satu dan nilai tertinggi lima untuk pernyataan positif, sedangkan pada pernyataan negatif menggunakan penilaian sebaliknya. Secara skor teoritik dengan rentang 97-136, sedangkan hasil penelitian dilapangan selain skor rerata, standar deviasi, skor maksimum dan skor minimum, maka dapat juga diperoleh hasil mediannya (Me) adalah 119, modus (Mo) adalah 120,50 dan kemiringan kurva sebesar -0,31. Data disusun dalam daftar distribusi frekuensi yang dihitung menggunakan rumus Sturges seperti pada tabel berikut :

Efektifnya pengorganisasian pembinaan siswa berbasis media sosial dapat diperjelas berdasarkan pada dimensi variabel penelitian yang dijawab oleh responden berkaitan dengan butirbutir instrumen. Penjelasan dimensi variabel efektifitas pengorganisasian pembinaan siswa berbasis media sosial yang dilakukan oleh wakil kepala sekolah bidang kesiswaan membuktikan keefektifannya.

a. Dimensi Struktur Organisasi

Dimensi struktur organisasi pada variabel efektifitas pengorganisasian pembinaan siswa berbasis media sosial dibagi dalam dua indikator yakni pembentukan dan koordinasi fungsi organisasi, menganalisis kerja organisasi. Pada masing-masing 
indikator dibagi dalam tiga butir pernyataan. Butir 1,2,3 pernyataanya berkaitan dengan indikator pembentukan dan koordinasi fungsi organisasi dan butir 4,5,6 pernyataannya berkaitan dengan indikator menganalisis kerja organisasi. Jawaban pernyataan berdasarkan pada skala likert. Skor tertinggi 5 dan terendah 1 dengan kategori sangat sering (SS), sering (S), jarang (J), hampir tidak pernah ( HTP) dan tidak pernah ( TP) sedangkan jawaban negatif dengan skor terendah 1 (SS) dan skor jawaban tertinggi 5 (TP).

b. Dimensi Pendelegasian Wewenang Melalui Media Sosial

Dimensi pendelegasian wewenangpada variabel efektifitas pengorganisasian pembinaan siswa berbasis media sosial dibagi dalam dua indikator yakni pemberian batas wewenang dalam organisasi dan pemberian informasi perkembangan organisasi. Pada masing-masing indikator dibagi dalam enam butir pernyataan. Butir 7 sampai12 pernyataanya berkaitan dengan indikator pemberian batas wewenang dalam organisasi dan pada butir 13 sampai 18 pernyataannya berkaitan dengan pemberian informasi perkembangan organisasi. Jawaban pernyataan berdasarkan pada skala likert. Skor tertinggi 5 dan terendah 1 dengan kategori sangat sering (SS), sering (S), jarang (J), hampir tidak pernah ( HTP) dan tidak pernah ( TP) sedangkan jawaban negatif dengan skor terendah 1 (SS) dan skor jawaban tertinggi 5 (TP). Setelah kuisioner disebarkan, maka diperoleh hasil pada butir 7 sampai 18 yang mendapat skor $5=127$, skor $4=161,3=111$ dan $2=33$.

\section{c. Dimensi Pembagian Tugas Berbasis Media Sosial}

Dimensi pembagian tugas pada variabel efektifitas pengorganisasian pembinaan siswa berbasis media sosial dibagi dalam satu indikator yakni penentuan spesialisasi kemampuan. Pada indikator dibagi dalam enam butir pernyataan. Butir 19 sampai 24 pernyataanya berkaitan dengan indikator penentuan spesialisasi kemampuan. Jawaban pernyataan berdasarkan pada skala likert. Skor tertinggi 5 dan terendah 1 dengan kategori sangat sering (SS), sering (S), jarang (J), hampir tidak pernah ( HTP) dan tidak pernah ( TP) sedangkan jawaban negatif dengan skor terendah 1 (SS) dan skor jawaban tertinggi 5 (TP). Setelah 
kuisioner disebarkan, maka diperoleh hasil pada butir 19 sampai 24 yang mendapat skor $5=55$, skor $4=75,3=62$ dan $2=24$.

\section{d. Dimensi Hubungan kerja Berbasis Media Sosial}

Dimensi hubungan kerja pada variabel efektifitas pengorganisasian pembinaan siswa berbasis media sosial dibagi dalam satu indikator yakni penentuan mekanisme kerja. Pada indikator dibagi dalam enam butir pernyataan. Butir 25 sampai 30 pernyataanya berkaitan dengan indikator penentuan mekanisme kerja. Jawaban pernyataan berdasarkan pada skala likert. Skor tertinggi 5 dan terendah 1 dengan kategori sangat sering (SS), sering (S), jarang (J), hampir tidak pernah ( HTP) dan tidak pernah ( TP) sedangkan jawaban negatif dengan skor terendah 1 (SS) dan skor jawaban tertinggi 5 (TP). Setelah kuisioner disebarkan, maka diperoleh hasil pada butir 25 sampai 30 yang mendapat skor $5=53$, skor $4=72,3=62$ dan $2=24$.

\section{e. Dimensi Mengidentifikasi Karakteristik Melalui Media Sosial}

Dimensi mengidentifikasi karakteristik pada variabel perilaku kepemimpinan wakil kepala sekolah bidang kesiswaan berbasis media sosial dibagi dalam dua indikator yakni penunjukan rasa empati dan pemberi motivasi yang tinggi. Pada indikator dibagi dalam sebelas butir pernyataan. Butir 1 sampai 5 pernyataanya berkaitan dengan indikator penunjukan rasa empati dan Butir 6 sampai 11 pernyataanya berkaitan dengan indikator pemberi motivasi yang tinggi. Jawaban pernyataan berdasarkan pada skala likert. Skor tertinggi 5 dan terendah 1 dengan kategori sering sekali (SS), selalu (S), kadang-kadang $(\mathrm{KK})$, jarang $(\mathrm{J})$ dan tidak pernah ( TP) sedangkan jawaban negatif dengan skor terendah 1 (SS) dan skor jawaban tertinggi 5 (TP). Setelah kuisioner disebarkan, maka diperoleh hasil pada butir 1 sampai 11 yang mendapat skor $5=132$, skor $4=185,3$ $=77$ dan $2=2$.

\section{f. Dimensi Metode Mempengaruhi Melalui Media Sosial}

Dimensi metode mempengaruhi pada variabel kepemimpinan wakil kepala sekolah bidang kesiswaan berbasis media sosial dibagi dalam dua indikator yakni Mendorong 
anggota melaksanakan tugas dan Pengambilan ke putusan dengan pertimbangan yang matang. Pada indikator dibagi dalam sebelas butir pernyataan. Butir 12 sampai 17 pernyataanya berkaitan dengan indikator penunjukan rasa empati dan Butir 18 sampai 22 pernyataanya berkaitan dengan indikator pemberi motivasi yang tinggi. Jawaban pernyataan berdasarkan pada skala likert. Skor tertinggi 5 dan terendah 1 dengan kategori sering sekali (SS), selalu (S), kadang-kadang $(\mathrm{KK})$, jarang $(\mathrm{J})$ dan tidak pernah ( TP) sedangkan jawaban negatif dengan skor terendah 1 (SS) dan skor jawaban tertinggi 5 (TP). Setelah kuisioner disebarkan, maka diperoleh hasil pada butir 1 sampai 11 yang mendapat skor $5=132$, skor $4=185,3$ $=77$ dan $2=2$.

g. Dimensi Penggunaan Kewenangan Melalui Media Sosial

Dimensi penggunaan kewenangan pada variabel kepemimpinan wakil kepala sekolah bidang kesiswaan berbasis media sosial dibagi dalam dua indikator yakni pengembangan semangat kebersamaan dan berkomitmen pada kritik yang membangun. Pada indikator dibagi dalam delapan butir pernyataan. Butir 23 sampai 27 pernyataanya berkaitan dengan indikator pengembangan semangat kebersamaan dan Butir 28 sampai 30 pernyataanya berkaitan dengan indikator berkomitmen pada kritik yang membangun. Jawaban pernyataan berdasarkan pada skala likert. Skor tertinggi 5 dan terendah 1 dengan kategori sering sekali (SS), selalu (S), kadang-kadang (KK), jarang (J) dan tidak pernah ( TP) sedangkan jawaban negatif dengan skor terendah 1 (SS) dan skor jawaban tertinggi 5 (TP). Setelah kuisioner disebarkan, maka diperoleh hasil pada butir 23 sampai 30 yang mendapat skor $5=82$, skor $4=115,3=85$ dan $2=6$.

Berdasarkan pada distribusi frekuensi data efektifitas pengorganisasian pembinaan siswa dan perilaku kepemimpinan wakil kepala sekolah bidang kesiswaan berbasis media sosial yang memiliki frekuensi diatas rata-rata, maka penggunan media sosial dalam melakukan pengorganisasian pembinaan siswa berdasarkan pada perilaku kepemimpinan wakil kepala sekolah bidang kesiswaan sangat memiliki pengaruh yang kuat, efektif dan efisien dalam memabangun komunikasi. 
Hipotesis yang dikembangkan dalam penelitian ini adalah tentang peran perilaku kepemimpinan wakil kepala sekolah bidang kesiswaan dalam melakukan pengorganisasian pembinaan siswa berbasis media sosial yang efektif, efisien dan komunikatif. Artinya, kempemimpinan wakil kepala sekolah bidang kesiswaan yang menggunakan media sosial secara aktif dalam melakukan komunikasi pada stakeholder Unit Kegiatan Sekolah (UKS) maka akan mempengaruhi kualitas pengorganisasian pembinaan siswa yang dilakukan oleh wakil kepala sekolah bidang kesiswaan di Sekolah Menengah Kejuruan. sebaliknya, apabila wakil kepala sekolah bidang kesiswaan melakukan komunikasi dengan cara konvensional, tanpa menggunakan media sosial dalam melakukan pengorganisasian pembinaan siswa, maka pengaruh wakil kepala sekolah bidang kesiswaan melakukan pengorganisasian pembinaan siswa menjadi kurang efektif

Pada metode analisis jalur hasilpersamaan regresi peran perilaku kepemimpinan wakil kepala sekolah bidang kesiswaan dalam pengorganisasian pembinaan siswa berbasis media sosial menghasilkan arah koefisien regresi "b" sebesar 1,12 dan konstanta "a" sebesar-19,35. Dengan demikian bentuk korelasi antara perilaku kepemimpinan wakil kepala sekolah bidang kesiswaandengan efektifitas pengorganisasian pembinaan siswa berbasis media soisal digambarkan oleh persamaan regresi $\hat{Y}=$ $19,35+1,12 \mathrm{X}_{2}$. Sebelum untuk prediksi, persamaan regresi ini harus memenuhi syarat kelinearan dan keberartian

Untuk mengetahui derajat keberartian dan kelinearan persamaan regresi, maka dilakukan uji F. Hasil keberartian regresi diperoleh $F_{\text {hitung }}$ sebesar 118,11 lebih besar $F_{\text {tabel }}$ sebesar 4,13 pada dk pembilang 1 dan dk penyebut 34 pada taraf nyata $\alpha=0,05$, sehingga dapat disimpulkan bahwa persamaan regresi $\hat{Y}=-19,35+1,12 X_{2}$ adalah signifikan.

Hasil penelitian ini menunjukan koefisien peran perilaku kepemimpinan wakil kepala sekolah bidang kesiswaan terhadap pengorganisasian pembinaan siswa berbasis media sosial sebesar 0,78. dari hasil hipotesis diperoleh $F_{\text {hitung }}$ sebesar 71,73 
lebih besar $\mathrm{F}_{\text {tabel }}$ sebesar 3,30 pada dk pembilang 2 dan $\mathrm{dk}$ penyebut 33 pada taraf nyata $\alpha=0,05$, Selanjutnya dilakukan pengujian hipotesis dengan uji " $t$ ". Dari hasil diperoleh hasil $\mathrm{t}_{\text {hitung }}$ adalah 10,87 sedangkan $\mathrm{t}$ pada tabel adalah 1,697 pada taraf signifikan $\alpha=0,05$. Dengan demikian $t_{\text {hitung }}>$ dari $t_{\text {tabel }}$, maka korelasi sangat signifikan.

Kekuatan peran kepemimpinan wakil kepala sekolah bidang kesiswaan terhadap pengorganisasian pembinaan siswa berbasis media sosial dinyatakanpersamaan regresi $\hat{Y}=-19,35+1,12$ $\mathrm{X}_{1}$ regresi menunjukan bahwa setiap kenaikan satu poin skor peran perilaku kepemimpinan wakil kepala sekolah bidang kesiswaan berbasis media sosial akandiikuti oleh kenaikan skor yang mempengaruhi pengorganisasian pembinaan siswasebesar 1,12 poin pada konstanta sebesar -19,35. Koefisien determinasi perilaku kepemimpinan wakil kepala sekolah bidang kesiswaan terhadap pengorganisasian pembinaan siswa adalah sebesar $\mathrm{R}^{2}$ $=0,78^{2}=0,6084$, sehingga perilaku kepemimpinan wakil kepala sekolah bidang kesiswaanmemberikan kontribusi sebesar 60,84 $\%$. Artinya 60,84 \% varians efektifitas pengorganisasian pembinaan siswa dapat dijelaskan oleh persamaan regresi $\hat{Y}=$ $19,35+1,12 \mathrm{X}_{2}$ Dari hasil analisis sederhana tersebut dapat disimpulkan bahwa terdapat pengaruh yang signifikan peran perilaku kepemimpinan wakil kepala sekolah bidang kesiswaan dengan efektifitas pengorganisasian pembinaan siswa berbasis media sosial.

Berdasarkan pada pengujian hipotesis tersebut dapat dinyatakan bahwa peran perilaku kepemimpinan wakil kepala sekolah bidang kesiswaan mempengaruhi secara signifikan efektifitas pengorganisasian pembinaan siswa berbasis media sosial. Artinya, cara komunikasi yang baik perilaku kepemimpinan wakil kepala sekolah bidang kesiswaan menggunakan media sosial memberikan pengaruh yang sangat signifikan terhadap efektifitas pengorganisasian pembinaan siswa.

\section{Simpulan}


Dari hasil penelitian tersebut, maka ada beberapa kesimpulan yang diperoleh sebagai berikut :

1. Hasil pengujian hipotesis dengan menggunakan koefisien korelasi dan regresi sederhana, menyatakan bahwa "peran perilaku kepemimpinan wakil kepala sekolah bidang kesiswaan yang berkomunikasi dengan baik mempengaruhi secara signifikan terhadap efektifitas pengorganisasian pembinaan siswa" hal ini, diinyatakan dari hasil koefisien korelasi peran perilaku kepemimpinan wakil kepala sekolah bidang kesiswaan terhadap efektifitas pengorganisasian pembinaan siswa berbasis media sosial sebesar 0,78. dan pengujian hipotesis dengan uji " $t$ "diperoleh $t_{\text {hitung adalah }}$ 10,87 lebih besar dari $t$ tabel adalah 1,697 pada taraf signifikan $\alpha=0,05$.

2. Kekuatan peran perilaku perilaku kepemimpinan wakil kepala sekolah bidang kesiswaan terhadap pengorganisasian pembinaan siswa berbasis media sosial dinyatakan oleh persamaan regresi $\hat{Y}=-19,3508+1,12 \mathrm{X}_{2}$. regresi menunjukan bahwa setiap kenaikan satu poin skor peran kepemimpinan wakil kepala sekolah bidang kesiswaan akan diikuti kenaikan skor yang mempengaruhi efektifitas pengorganisasian pembinaan siswasebesar 1,12 poin pada konstanta sebesar -19,35.

\section{Daftar Pustaka}

Atmodiwirio, Soebagio. 2005, Manajemen Pendidikan Indonesia, Jakarta: Ardadizya Jaya.

Black, Jack M. 2010. Management: A Guide to Executive Command. Ohio: publishing co.

Clinton, J. Robert and Y. Tomatala. 2017. The Making of A Leader. Retrieved 3 juli 2017 http : Leadership .blogspot.com/ definition Leadership.html.

Depertemen Pendidikan Nasional.2014. "Proyek dan Pengembangan Sistem dan Standar Pengelolaan SMK 
Direktorat Pendidikan Menengah Kejuruan Jakarta”.2009.118.98.163.253/download/view.php?file.P engorganisasian.htm

Facebook. (2017). "Facebook Privacy Policy." Retrieved August 6, 2017, from

Falls, J. (2017). "Social Media in Two Words or Less." Retrieved August 6, 2017, from http://www.socialmediaexplorer.com/2017/07/31/socialmedia-in-two words or-less/

Furqon. 2014. Statistik Terapan Untuk Penelitian. Bandung: Alfabeta.

Hanaka, Martin E dan Bill Hawkins.2016. "Mengorganisasi Untuk Keunggulan Terus-Menerus"dalam Frances Hesselbein, Marshall Goldsmith dan Richard Bechard.2016. The Organization of the Future.Jakarta: ELex Media Komputindo.

Hanna, David, P.2015. Manajemen Pendidikan. Jakarta : Erlangga.

Hasibuan,Melayu S.P. 2010, Pengorganisasian dan Organisasi. Retrieved 14 Juli 2017, Open pdf.com /ebook/pengorganisasian- pdf-html.

Haenlein, Frances and Marshal Goldsmith. 2017. The Leader of The Future: Visi, Strategic dan Praktik Pemimpin Masa Depan Untuk Era Baru. Jakarta: Elex Media Kompetindo.

http://www.teachthought.com/technology/10-different-socialmedia-sites-for-education/

https://id.wikipedia.org/w/index.php?search=media+sosial+adal ah\&title=Istimewa:Pencarian\&go=Lanjut\&searchToken =etbiozowy95mfe9of3qqd1ojc

Kaplan, Andreas and Michael Haenlein. 2017, "Users of the world, unite! The challenges and opportunities of Social Media". Business Horizons 
Nasihin, Sukarti dan Sururi.2015,Manajemen Peserta Didik. Bandung : Alfabeta.

Nisrul Irawati, Nisrul. 2014. Kepemimpinan Efektif: Kepemimpinan Yang Mampu Mengambil Keputusan Yang Tepat. Medan: USU Digital Library.

Reuben, Rachel (2008) "The Use of Social Media in Higher Education for Marketing and Communications: A Guide for Professionals in Higher Education" retrieved 5 Juli 2017 From http://www.rachelreuben.com/.../socialmedia-uses-higher-educati...

Purwanto, M. Ngalim,.2011. Administrasi dan Supervisi Pendidikan. Bandung : Remaja Rosda Karya

Soekarno K. 2016. "Fungsi-Fungsi Manajemen". retrieved, 02 Juni 2017 Open pdf.com/ebook/pengorganisasian- pdfhtml.

Terry and Tead. 2010. Kemimpinan-fisipuh., retrieved 5 juli 2017, blospot.com/.../defenisi kepemimpinan.html.

Thoha, Miftah. 20013. Kepemimpinan Dalam Manajemen. Jakarta : Rajawali Pers

Thomas Gordon, Thomas.2010. "Group Centered Leadership: A way Of releasing creative power of Group". Retrieved 19 Juni 2017, http : Leadership .blogspot.com/ definition Leadership. html.

Wahjosumidjo.2010.Kepemimpinan Kepala Sekolah: Tinjauan Teoritik dan Permasalahannya. Jakarta: Rajawali press.

Warella, Y.2017. Pengorganisasian komunitas. Open pdf.com/ebook/pengor ganisasian- pdf-html

Wordpress.com/2009/03/11/manajemen-kesiswaan-2.html

Yukl, Gary.2013. Kepemimpinan Dalam Organisasi. Jakarta : Prenhallindo.

Yahya, Sani.2016."Transformational Leadership". Retrieved 19 Juni 2017, http://Stralead-Change.com/files/corses.htm 